\title{
Analysis of lightning-induced forest fires in Austria
}

\author{
Mortimer M. Müller • Harald Vacik • \\ Gerhard Diendorfer • Alexander Arpaci • \\ Herbert Formayer • Hartmut Gossow
}

Received: 31 October 2011 / Accepted: 4 April 2012 /Published online: 1 May 2012

(C) The Author(s) 2012. This article is published with open access at Springerlink.com

\begin{abstract}
Besides human-caused fires, lightning is the major reason for forest fire ignition in Austria. In order to analyse the causes of ignition and to characterise lightning-induced forest fires, fire records were compared with the real appearance of lightning events by using the Austrian Lightning Detection and Information System for the period from 1993 to 2010. A probability was estimated for each forest fire being caused by lightning by using a decision tree and decision matrices based on flash characteristics (e.g. amplitude, time, location). It could be shown that $15 \%$ of documented forest fires were lightning-caused. Nearly all lightning-caused fires were found during the summer months, whereas almost $40 \%$ of all fires occurring from June to August were naturally caused. Most
\end{abstract}

M. M. Müller $(\bowtie) \cdot H$. Vacik $\cdot$ A. Arpaci

Department of Forest and Soil Sciences, Institute of Silviculture,

University of Natural Resources and Life Sciences (BOKU),

Peter Jordan Str. 82,

1190 Vienna, Austria

e-mail: mortimer.mueller@boku.ac.at

G. Diendorfer

Department ALDIS (Austrian Lightning Detection \& Information

System), Austrian Electrotechnical Association (OVE),

Kahlenberger Straße 2A,

1190 Vienna, Austria

H. Formayer

Department of Water, Atmosphere and Environment, Institute of Meteorology,

University of Natural Resources and Life Sciences (BOKU),

Peter Jordan Str. 82,

1190 Vienna, Austria

H. Gossow

Department of Integrative Biology and Biodiversity Research, Institute of Wildlife Biology and Game Management,

University of Natural Resources and Life Sciences (BOKU),

Gregor Mendel Str. 33,

1190 Vienna, Austria lightning-caused fires took place in the south and east of Austria. Lightning fires were more frequent at higher altitudes and primarily affected conifer forests. The median burned area was lower than that for anthropogenic forest fires.

\section{Introduction}

Particularly in the temperate mountain forests of Central Europe, forest fires have played only a minor role so far. Forest fires are a result of complex interactions between ecological factors such as weather, fuel type, forest structure and topography as well as socioeconomic factors. Several studies have identified various factors such as climate change (Badeck et al. 2003; Flannigan et al. 2000; Reinhard et al. 2005; Wendler et al. 2010), human factors (VegaGarcia et al. 1995; Goldammer 2002) or land use change due to socioeconomic factors (Badia et al. 2002) potentially influencing forest fire hazard. According to the climatic change, European mountain regions may experience somewhat higher increases in temperature compared to nonmountainous regions. In the Alps, an increase in temperature twice the global average was observed over the last century (Auer et al. 2007). Austria is a Central European country largely dominated by the Alps with a forest cover primarily dominated by coniferous tree species. The forests do not fulfil the characteristics of fire-prone ecosystems nor have they seriously been fire-impacted so far. However, two fire seasons (2003 and 2007) have recently proved quite well that forest fires may happen widespread and rapidly. It seems likely that they might become an important issue in the case of the occurrence of certain weather extremes such as prolonged periods of drought or heat waves (Barriopedro et al. 2011; Fischer and Schär 2010; Gimmi et al. 2004; Gossow and Frank 2003; Gossow et al. 2009). In the 
context of the Austrian Forest Fire Research Initiative (AFFRI), one major objective is to identify forest fire "hot spots" in Austria in dependence of vegetation, climate and location and if there is likely a chance for expansion under the effects of climate change. This includes the consideration of fire weather options and topoclimatological aspects, as well as the classification of forest fuels for both, the more firesensitive forest types and for more fire-endangered regions, especially in the mountain forests.

An important prerequisite for the intensified forest fire studies in Austria was an improved documentation of such events. Some years ago, fire record data were still rather incomplete and biased (for instance, with respect to fire damage compensation claims, cf. Vacik et al. 2011). Since 2002, the Austrian firefighting brigades started to document their fire attacks on their websites, which improved data access more general. However, the causes of ignition are often unknown (Vacik et al. 2011). Like elsewhere, also in Austria anthropogenic ${ }^{1}$ forest/wildland fire causes are dominating. But also naturally ignited forest fires, with lightning flashes as the only relevant natural cause in Austria, play a remarkable role - up to $40 \%$ in the summer months in the last decade on average. These findings are most relevant in the three (so far) evidenced forest fire hot spots in parts of Carinthia, Lower Austria and Tyrol.

In many studies, the number and distribution of lightningcaused forest fires is based on the available information of fire brigades, national authorities and/or the documentation of forest owners (e.g. Castedo-Dorado et al. 2011; Conedera et al. 2006; Hall and Brown 2006). The declaration "lightning fire" is taken as confidential. Nevertheless, it cannot be ruled out that in most data records on forest fires, there might be still some bias in the causes of ignition - especially towards lightning cause - due to inaccurate documentation (e.g. thunderstorm some days ago but no proven ignition), or juridical reasons (e.g. fires caused by humans might have been declared as lightning to prevent possible claims for indemnity). To reduce these uncertainties, it seems to be necessary to compare assumed lightning fires with the real occurrence of flashes at the forest fire locality.

This contribution describes the verification of forest fires caused by lightning, carried out with the help of a combined use of a decision tree and decision matrices, where the most relevant parameters of flashes (e.g. number, multiplicity, distance, time of impact, location accuracy) and their possible relation to forest fires are considered. The objectives of the current study are as follows: (a) to describe the methodological approach taken to detect lightning-caused forest

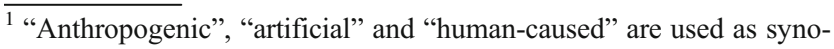
nyms, describing all forest fires ignited by the direct (e.g. fires out of control) and indirect (e.g. power lines) influence of humans.
}

fires in the period from 1993 to 2010 and (b) to characterise lightning-caused forest fires (e.g. time, location, forest types) in Austria.

\section{Material and methods}

\subsection{Location of forest fire records}

In order to characterise recent forest fires in Austria, a wildfire database has been established (for details, see Vacik et al. 2011). "Forest fires" were defined as uncontrolled fires in wooded areas declared as "forest" by the Austrian forest law (FG 2007), also including clear cuts, blowdowns, small groves and dwarf mountain pine (Pinus mugo Turra) areas above timber line. Besides online blogs and homepages from fire brigades, reports from the Austrian Press Agency, the documentation of the Austrian Federal Forests (ÖBF), the Federal Ministry of Agriculture and Forestry, Environment and Water Management, the Austrian Railway Company and archive data from municipalities were used to document information on forest fires in Austria. In many cases, the gained information was incomplete, as the exact time of detection, size of the burned area, concerned tree species or cause of ignition were missing. The location of each forest fire was estimated by the use of road names, distances to important objects (like churches, mountain shelters) or by analysing photos made during the firefighting operations. In any case, the location of a forest fire was linked to a wooded area. As not in all cases information on the exact location of the forest fire was available, a buffer radius was established for each record indicating the accuracy of the documented location. According to the specifics of each fire record, a buffer was placed around the assumed ignition point. The medium buffer radius for all forest fires was around $1,500 \mathrm{~m}$. The highest accuracy according to the location was reached with a resolution of 1 " in the World Geodetic System 1984 (WGS84), which comprises $30 \mathrm{~m}$ for the latitude and, in Austria, $20 \mathrm{~m}$ for the longitude (Müller 2010). A detailed description of the wildfire database and its characteristics is provided by Vacik et al. (2011).

\subsection{Austrian lightning detection and information system} lightning detection

The Austrian Lightning Detection and Information System (ALDIS) as lightning location system (LLS) locates and records lightning and thunderstorm activity inside and nearby of Austria. The detection efficiency since 1999 on cloud to ground flashes is $98 \%$. This makes it one of the best-performing LLS worldwide (ALDIS 2009; Anderson 2002; Biagi et al. 2007; Castedo-Dorado et al. 2011; Diendorfer 2007; Outcalt 2008; Podur et al. 2003). The first detection sensor was put into operation in 1991, 
and archived lightning data are available since 1993. Currently, eight sensors are in use, each with an operation range of about $400 \mathrm{~km}$. In 2006, the sensors were replaced by new ones (LS7000), which offer a complete digital signal processing.

The ALDIS basically consists of three components. First are the sensors, which measure and report the angle of field incidence and exact field arrival time at the sensor site. Second is the central lightning processor, which calculates the point of impact. The third is a display system for the graphical view of thunderstorm activity (ALDIS 2009). There are two different methods to determine the point of impact of a lightning stroke: either with magnetic direction finding or with time differences (time of arrival). As ALDIS sensors provide both information (angle and time), a combined method is used, whereby already two sensors are sufficient to calculate the location of a specific lightning stroke. The temporal uncertainty is around $250 \mathrm{~ns}$, and the median location accuracy below $400 \mathrm{~m}$ (Diendorfer 2007). Strokes are grouped into flashes using a spatial clustering algorithm where strokes are added to any active flash for a specified time period (usually $1 \mathrm{~s}$ ) after the first stroke, as long as the additional strokes are within a specified clustering radius (usually $10 \mathrm{~km}$ ) of the first stroke, and the time interval from the previous stroke is less than a maximum interstroke interval (usually $500 \mathrm{~ms}$ ). Beside the coordinates of the strike point, the lightning processor provides information on the exact time, the polarity of the flash (positive or negative) and the flash peak current in kiloampere (kA). The value associated with the first return stroke in the flash is assigned by the system as flash peak current.

The coordinates for each forest fire event in the evaluation period from 1993 to 2010 with unknown or assumed lightning cause were used to identify relevant lightning flashes detected by ALDIS, which occurred $-10 /+1$ days prior or after the proposed date of the forest fire and within a buffer radius of $10 \mathrm{~km}$ to the location point of the fire. Forest fires declared as human-caused were excluded from the analysis because a previous study has shown that these fires do not correspond to a relevant number of flashes (Müller 2010). Based on the coordinates of the chosen forest fires, a set of parameters for each fire record was established, which provided information about the date and time (to the second) for each lightning, coordinates of the flash in WGS84 (X, Y), strength in kiloampere and charge (positive or negative), number of strokes $(n)$, distance to location point of forest fire (in kilometres), information about the direction of the flash (cloud to ground (CG) or cloud to cloud (CC)) and the median of the half axis of the error ellipse (in kilometres). Table 1 shows the decision matrix according to date and time of flash occurrence.

\subsection{Decision tree and decision matrices}

The procedure to estimate the probability for a forest fire being ignited by lightning followed a sequence of expert judgements. After the identification of relevant forest fires and the selection of corresponding data from ALDIS, the flashes, which most likely ignited a fire, had to be assessed. In order to identify relevant lightning flashes, a decision tree and related decision matrices were developed based on existing literature (e.g. Diendorfer 2007; Hall and Brown 2006; Larjavaara et al. 2005; Schulz et al. 2005) and on expert judgements of the research team. Each forest fire, respectively lightning flash, was evaluated separately, whereas in case of a higher number of possible flashes related to the recorded forest fire, only the four most relevant flashes were considered based on the following selection criteria: distance of a flash to the location of the forest fire ignition point, date of lightning ${ }^{2}$ and size of the error ellipse. As a consequence, up to four flashes could be considered as igniter. The final judgement about each case (if a forest fire was caused by lightning is indicated as "yes", "uncertain" or "no") was made after the analysis of these most relevant four flashes.

The procedure to estimate the probability for a forest fire being ignited by lightning was decomposed into four steps. The first step of the decision tree (Fig. 1) leads to a classification in five probability classes and provides an initial estimation of the likelihood for each flash. The used categories are "excluded" (flash eliminated from further analysis), "unlikely", "possible", "likely" and "very likely". Because ALDIS detects around $98 \%$ of all CG flashes in Austria (Diendorfer 2007), it was assumed that lightning could not have been the cause of the forest fire, if there were no flashes detected within the relevant time period. Single positive flashes under $10 \mathrm{kA}$ were excluded from the analysis too, even if they were the nearest events, because studies have shown that these flashes are mostly (more than $90 \%$ ) CC and not CG lightnings (Biagi et al. 2007; Diendorfer 2007; Hall and Brown 2006). Additionally, the probability for each lightning flash was estimated by the location accuracy of a specific flash (error ellipse). For each lightning sensor, which is involved in the detection of a stroke, a normally distributed measuring error sigma $(\sigma)$ for the angle and the time measurement are assumed. In expectation of a likelihood of, e.g. $50 \%$, the result is an ellipse, wherein the actual point of impact is located. This means that more involved lightning sensors lead to a smaller error ellipse or the wider the error ellipse, the more inexact the point of impact might be. The used ellipse in this study is the $50 \%$ error ellipse of a flash, which is the error

\footnotetext{
${ }^{2}$ Note that the date of lightning could be the first selection criterion as well, when the information of the fire brigade assumes a certain date without any insecurity.
} 


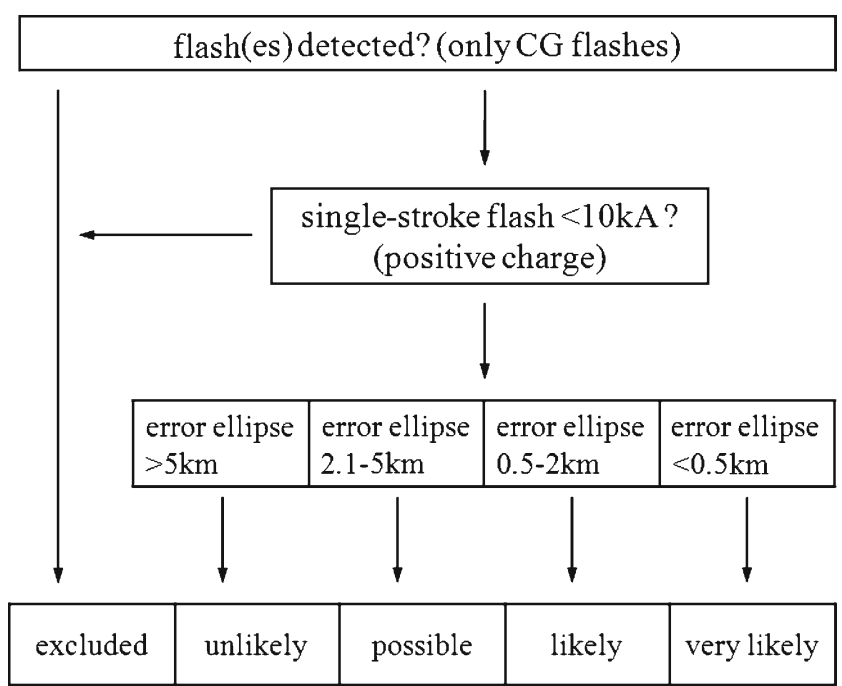

Fig. 1 Decision tree analysing location accuracy for a specific flash (step 1)

ellipse of the first stroke in case of a multi-stroke flash. It is important to note that the error ellipse shows linear distances and does not consider the topography. The applied threshold values are based on the distribution of error ellipse values, the expected influence of the specified location accuracy on the potential wildfire ignition and the assumed buffer radii (Fig. 1 and Table 2).

The second step (Table 1) considers the parameter "time" of the analysed lightning. In the first and most common case, when time and date of the forest fire were certain, all flashes which occurred after and more than 6 days before the detection of the fire were excluded. For flashes which occurred 4- 6 days before the fire, the probability category was reduced by two probability classes; flashes which occurred 2-4 days before the fire resulted in a reduction of one class, and only those lightnings which appeared within $48 \mathrm{~h}$ before the time of the forest fire detection retained their probability class. This approach is a compromise between studies related to the accuracy of lightning location systems (Larjavaara et al. 2005), possible ignition delays (Duncan et al. 2010; Larjavaara et al. 2005) and the expertise from firefighters, which seem to suggest that lightnings can lead to smouldering fires, which burst into flames even some days later. Moreover, embers in a deep humus layer can last some days, even if firefighters try to damp down the fire (Conedera et al. 2006; Wotton and Martell 2005). Reports with an operating time up to 14 days are found in Austria. This also indicates a possible longer smouldering period after lightning ignition. In case of the assumption that the relevant lightning occurred some days earlier or the fire detection time was uncertain, the probability class was altered (as indicated in the columns 2-4 in Table 1). During the second step, the probability class of the lightning was reduced by one additional class, if the relevant flash concerned a positive single-stroke flash with an amplitude from 10 to $19 \mathrm{kA}$ because of an estimated incorrect CG classification of over $50 \%$ (Biagi et al. 2007).

Step 3 of the evaluation approach consists of four decision matrices - one for each preliminarily defined probability class. The relevant flashes assessed in step 2 were analysed in dependence on the size of the buffer radius of the forest fire and the distance of the flash to the buffer. A flash was classified with an even higher probability: the smaller the buffer and the closer the flash to the assumed location of the forest fire. As the error ellipse, the values of the buffer radius mean linear distances and do not consider the topography. Table 2 shows the classification procedure with "very likely" flashes (probability class after step 2). As it can be seen, lightnings with a distance of more than $2,000 \mathrm{~m}$ to the buffer radius of a forest fire are excluded due to the good performance of ALDIS, which means that with a median location accuracy of under $500 \mathrm{~m}$, it is very unlikely that a lightning more than $2 \mathrm{~km}$ outside the assumed location of a forest fire could have caused the fire.

Step 4 of the analysis represents the final classification of the evaluated flashes based on the individual assessments of each flash. Table 3 describes the cumulative probability that the recorded forest fire was caused by lightning, considering that in total, the most relevant four flashes were analysed during steps 1,2 and 3 . The probability classes were assigned a value of " 1 " for "very likely", " 0.5 " for "likely", " 0.2 " for "possible" and " 0.05 " for "unlikely" cases, which led to the final evaluation.

Table 1 Decision matrix according to date and time of flash occurrence (step 2, for details cf. text)

\begin{tabular}{lllll}
\hline Rated flash (after part 1) & Time/date certain & $\begin{array}{l}\text { Date certain, lightning some } \\
\text { days ago }\end{array}$ & $\begin{array}{l}\text { Time uncertain, } \\
\text { date certain }\end{array}$ & Time/date uncertain \\
\hline Flash next day after forest fire & Flash excluded & Flash excluded & Flash excluded & Probability class -1 \\
Flash same day after forest fire & Flash excluded & Flash excluded & Probability class -1 & Probability class -1 \\
Flash till 2 days before forest fire & Probability class unchanged & Probability class unchanged & Probability class unchanged Probability class -1 \\
Flash 2-4 days before forest fire & Probability class -1 & Probability class unchanged & Probability class -1 & Probability class -1 \\
Flash 4-6 days before forest fire & Probability class -2 & Probability class -1 & Probability class -2 & Probability class -1 \\
Flash 6-10 days before forest fire & Flash excluded & Probability class -2 & Flash excluded & Probability class -2 \\
\hline
\end{tabular}


Table 2 decision matrix according to distance of flash occurrence for "very likely" cases (step 3)

\begin{tabular}{lllll}
\hline Very likely (after part 2) & Distance flash $>2,000 \mathrm{~m}$ & Distance flash 500-2,000 m & Distance flash $<500 \mathrm{~m}$ & Flash in range \\
\hline Buffer radius 5,000 + & Excluded & Unlikely & Unlikely & Unlikely \\
Buffer radius 3,000-4,999 m & Excluded & Unlikely & Possible & Possible \\
Buffer radius $1,500-2,999 \mathrm{~m}$ & Excluded & Possible & Possible & Likely \\
Buffer radius $500-1,499 \mathrm{~m}$ & Excluded & Possible & Likely & Very likely \\
Buffer radius $<500 \mathrm{~m}$ & Excluded & Likely & Very likely & Very likely \\
\hline
\end{tabular}

Only the final classes "very likely" and "likely" (and "possible" for those cases, where the data sources suggest lightning fire as cause) were considered as lightning fires. The classes "unlikely" and "excluded" led to the decision that the forest fire was not caused by lightning. Fire events with primary unknown causes which reached the class "possible" (and "unlikely" if the fire brigade declared the fire as lightning-triggered) were considered as "unclear". In the course of the final evaluation, also the estimation by the fire brigades/forest experts regarding assumed causes were considered (primarily for those cases with likely anthropogenic causes). This means that even if the decision tree/matrices reached a "likely", the case was classified as "unclear" if the report of the involved firefighters highly suggests a humancaused fire. With the application of the presented methodological approach of decision trees and decision matrices, it was possible to analyse 964 forest fire events with unknown or assumed lightning cause from 1993 to 2010; 627 cases with known human cause were excluded from the evaluation.

\section{Results}

\subsection{Evaluation of forest fire causes}

Eighty-three percent of the forest fires that were supposed as being lightning fires could be classified with a high probability

Table 3 Final decision matrix according to the probability for a lightning-caused fire (step 4)

Number Evaluation of single Final evaluation (sum of probability of flashes event (after part 3) that forest fire was caused by lightning)

\begin{tabular}{lll}
\hline 1 & Very likely & Very likely \\
2 & Likely & Very likely \\
1 & Likely & Likely \\
3 & Possible & Likely \\
$1-2$ & Possible & Possible \\
4 & Unlikely & Possible \\
$1-3$ & Unlikely & Unlikely \\
\hline
\end{tabular}

as correct. Seven percent stayed "unclear", and for $10 \%$ of assumed lightning fires ignition through lightning could be ruled out. Five percent of the fires, where the cause was unknown, could be classified with a high probability as being lightning-caused. Here, $7 \%$ remained unclear, too; all other cases had to be excluded. All fire events with unclear causes were assigned to the "excluded" group, which means that they were considered as being not lightning-induced. As a result, $15 \%$ (236 cases) of all recorded forest fires in Austria were caused by lightning from 1993 to 2010 .

Table 4 shows the distribution of all analysed flashes per probability class and assigned cause. In each case, the lightning with the highest relevance was analysed first. For that reason, an "excluded" flash means that the whole case (forest fire) was spaced out from the possibility of being lightning induced, whereas no other flash could have gained a higher probability. It has to be said that for more than half of the forest fires, the ALDIS query revealed less than four or even none relevant flashes.

The analysed flashes in the lightning-caused fires are gaining a higher share in the likely, very likely and possible categories than forest fires with unknown cause. Additionally, the probability of being excluded seems to be ten times higher for forest fires with no delivered cause, compared to assumed lightning fires. It is interesting to note, that none of the initially supposed lightning-caused fires that were (according to the information of the fire brigades) very likely true lightning fires (59 cases, $25 \%$ of all assumed lightning fires) had to be excluded after the decision tree application.

Table 4 Number and percentage of all analysed lightnings with regard to preliminarily assumed causes of forest fires and flash categories

\begin{tabular}{lllll}
\hline Flash category & Lightning-caused & $\%$ & Cause unknown & $\%$ \\
\hline Excluded & 22 & 3.8 & 218 & 41.5 \\
Unlikely & 190 & 33.2 & 176 & 33.5 \\
Possible & 237 & 41.4 & 104 & 19.8 \\
Likely & 89 & 15.5 & 26 & 4.9 \\
Very likely & 35 & 6.1 & 1 & 0.3 \\
Sum & 573 & 100 & 525 & 100 \\
\hline
\end{tabular}




\subsection{Occurrence of lightning caused fires}

In absolute numbers, most lightning-caused forest fires occurred in Lower Austria, followed by Carinthia (Fig. 2). Especially in the southern part of Lower Austria in the region of the eastern edge of the Alps and in the South of Carinthia near the border to Italy/Slovenia, a high accumulation of lightning-induced forest fires could be found. Regarding the relationship to the lightning density for Austria in the period from 1992 to 2008 (ALDIS 2009), no clear correlation between the yearly average of the total number of lightning flashes and lightning fires could be detected.

Considering the impact on the forest area (number of lightning fires per square kilometre of forest area), most fires appeared in the South of Austria in Carinthia ( 0.9 fires per $100 \mathrm{~km}^{2}$ ), followed by Tyrol (0.8) (Fig. 3). Regarding the absolute number of forest fires and lightning fires per forested area, Salzburg seems to have the highest probability for a lightning-caused fire ( $23 \%$ of all forest fires).

\subsection{Temporal distribution}

The yearly distribution regarding the number of lightning fires differs distinctly. A higher number of lightning fires mostly correlated with a higher total number of forest fires (Fig. 4). In years with strong summer drought (e.g. 2003 and 2006), the proportion of lightning fires was higher than in other years as, for instance, those with a high amount of forest fires also in spring (e.g. 2007). The highest percentage of lightning fires regarding the total number of forest fires was found in 2006 (31\%). In relation to the total number of lightings per year, it becomes evident that more lightning flashes do not correlate with a higher number of lightningcaused fires.

Seasonally, nearly all lightning-caused fires were found during the months from May to September. Almost $40 \%$ of all forest fires occurring in the months of June to August are naturally caused, which demonstrates the relevance of the seasonal thunderstorms in Austria. Because not all fire records contained information of the exact time of the event, statistics on the daily distribution had to be done with a smaller amount of cases (Fig. 5). On an average, most lightning fires were documented in the mid-afternoon, with about a 2-h delay, compared to the peak of most humancaused fire reports.

\subsection{Burned area, forest type and altitudinal zone}

More than one third (35\%) of the human-caused fires as well as lightning fires were lacking information about the size of the burned area (553 and 83 cases). The distribution for all cases $(n=1191)$ with available data shows that around $40 \%$ of lightning fires burned no more than 0.01 ha, while human-caused fires in this category were fewer than $25 \%$. Fourteen percent of lightning fires affected more than 1 ha ( $18 \%$ of anthropogenic fires here). Only one lightning fire event $(0.7 \%)$ caused a burned area more than 9 ha, while it was $2 \%$ for human-caused fires. Regarding the burned area, the median was 0.02 ha for lightning fires and 0.05 ha for human-caused fires.

Compared to the appearance of human-caused fires, lightning fires were more concentrated on coniferous stands. More than $80 \%$ of all lightning-caused forest fires occurred in pure coniferous stands, while only $65 \%$ of the anthropogenic fires have been ignited in coniferous forests, both corresponding to the high amount of coniferous stands in Austria. Only a small number of lightning fires affected mixed $(9 \%)$ and broadleaf forests $(9 \%)$. Lightning fires on "open" forest stand areas (e.g. forest area after clear cuts, on salvage-logged blowdowns or disturbances as by bark beetle impacts) were not very relevant $(0.5 \%)$.

Significant differences could be found out concerning the altitudinal distribution of human-caused and of lightning fires. As the altitudinal zones depend on the ecozones, it was possible that two lightning fires dropped into the "alpine" zone, a region where normally no forest area exists. These fires and some events from the "high subalpine" zone affected the dwarf mountain pine zone (P. mugo Turra), which exceed the alpine tree line. Figure 6 indicates that fires initiated by thunderstorm activity concentrated on the "low montane" and "middle montane" zone (47\%), while human-caused fires were most frequent at the "submontane" zone (39 \%). Nearly all cases in the "high subalpine" zone and both events which occurred in the "alpine" zone were lightning-caused. So there is a clear tendency towards higher altitudes concerning lightning fires.

\section{Discussion}

\subsection{Decision tree application}

The main sources of our database were reports from fires brigades. The cited causes were either natural (i.e. lightningcaused), unknown or human-caused. A former analysis confirmed that the declaration of "human-caused" is plausible in most cases (Müller 2010). According to the reports of the fire brigades, 242 forest fires were ignited by lightning from 1993 to 2010. It is interesting to note that after our evaluation, the number was nearly the same (236, cf. "Section 3.1"). However, 42 preliminary supposed lightning fires (17\%) had to be excluded due to nonrelevant lightning flashes. Conversely, 36 fires with unknown cause could be assumed as lightning fires. It seems that the declaration "lightningcaused", done by the fires brigades, is correct in over $80 \%$ but cannot be taken as verified in each case. Especially in 


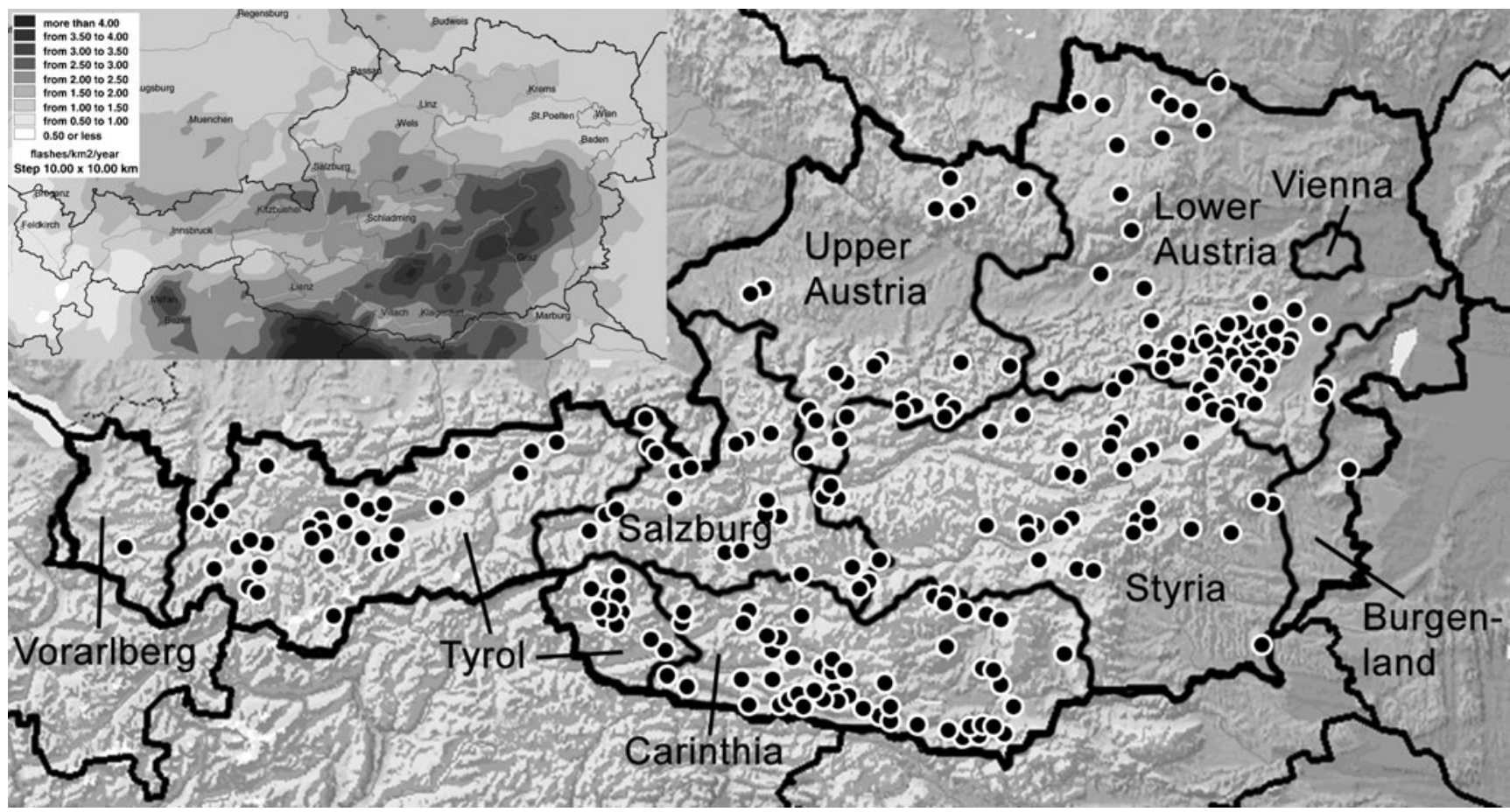

Fig. 2 Spatial distribution of lightning-caused forest fires in Austrian districts from 1993 to $2010(n=236)$ and density of lightning flashes from 1992 to 2008 (small map)

uncertain cases, a validation based on the presented decision tree approach seems promising.

One problem in the present evaluation was the wide range of the buffer radius for the location of the ignition point since the forest fire database in Austria was assembled from different sources and by several team members. As the estimation of the buffer is partly subjective, some lightning fires may have been erroneously included or excluded due to wrongly considered buffer radii. Another critical point in the analysis was the uncertainty of the date and exact
Fig. 3 Human-caused forest fires and lightning fires, related to provinces and forested area (in hectares)

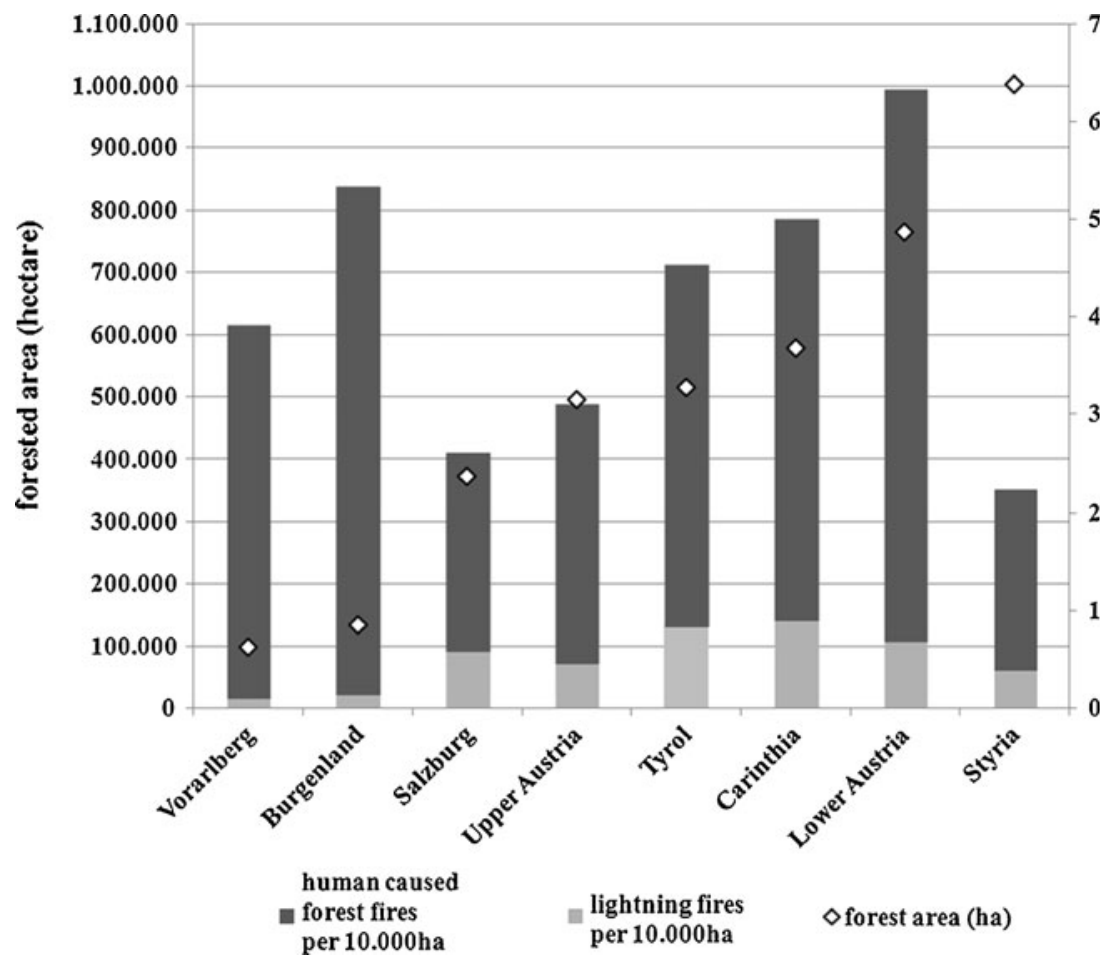


Fig. 4 Yearly distribution of human and lightning-caused forest fires $(n=1591)$ as well as total number of lightning flashes

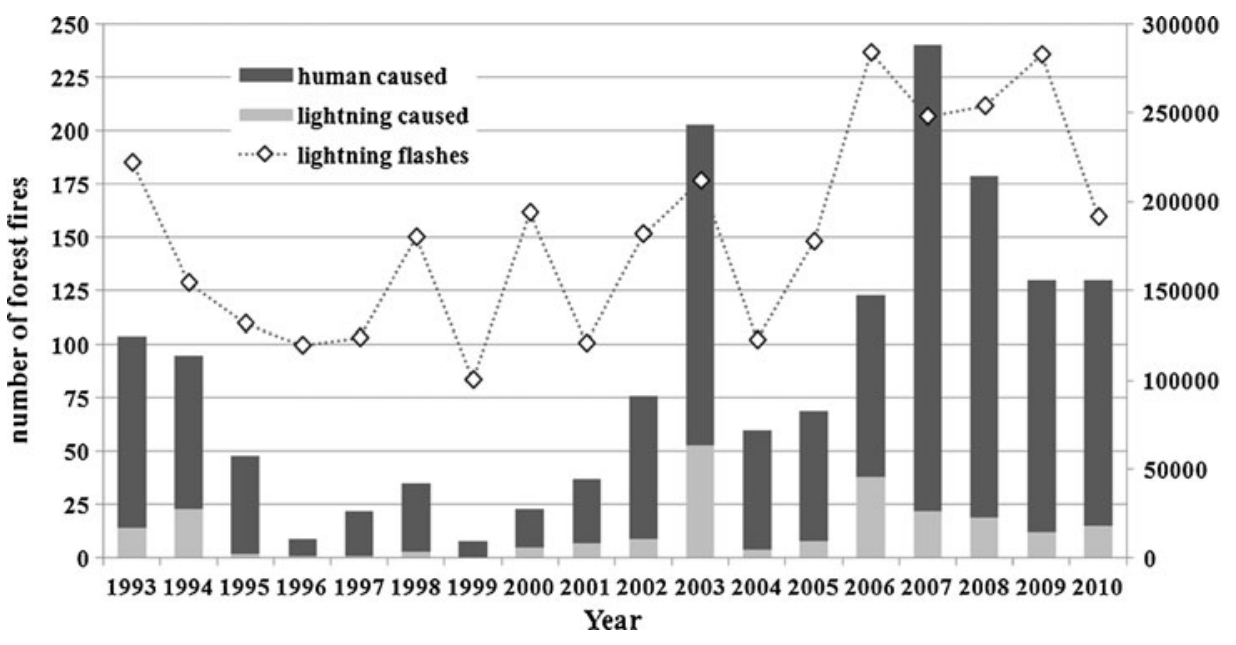

location of some forest fire events, especially before the year 2000. Hence, it is possible that a few of these fires were wrongly considered as lightning-caused or falsely excluded.

Another uncertainty is related to the detection efficiency (DE) of ALDIS. While studies have shown that DE since 1998 reached clearly above $90 \%$ with an estimated value of $98 \%$ (Schulz et al. 2005; Diendorfer 2007), DE in former years was somewhat lower (around $85 \%$ ). For that reason, especially in the time period from 1993 to 1997, some relevant flashes in the query performed by ALDIS might be missing. Nevertheless, we assume that this effect does not influence the results, as thunderstorm activity in the summer months is mostly coupled with a higher number of flashes. Additionally, the data query for some forest fires in the years 1993-1995 gained no information about the error ellipse of the relevant lightnings due to insufficiency of data processor power. For these forest fires (46 in total), the error ellipse was assumed as being " 0 ", leading to a preliminary classification as "very likely". This can be justified by the fact that the location accuracy of forest fires in this time period is worse than in subsequent years, and the performance of ALDIS showed reasonable results from the start of its service in 1993 (Diendorfer 2007).

Larjavaara et al. (2005) first tried to link single flashes to the ignition point of a forest fire. Other studies have not done this so far (Castedo-Dorado et al. 2011; Wotton and
Martell 2005). Therefore, it would be promising to apply the approach to other contexts in order to discuss the results derived from these studies. However, when the method would be utilised in other countries, an adaptation according to the used lightning location system, quality and preparation of forest fire data would become necessary.

\subsection{Characteristics of lightning fires}

The results from the analysis showed a relative amount of $15 \%$ lightning fires in Austria. This percentage seems to be realistic regarding other studies from the alpine region (e.g. Conedera et al. 2006; Valese 2007). Conedera et al. (2006) have described that lightning fires in the whole alpine region of Switzerland make up for about $9 \%$ of all forest fires, while they account for about $25 \%$ in the Canton of Grisons. Valese (2007) has identified that lightnings in the northern parts of Italia near the border to Austria were the cause for around $10 \%$ of all forest fires. It seems reasonable that the high amount of forest area in Austria (nearly $50 \%$ of total land area), the Europe-wide surpassing thunderstorm activity (cf. in Fig. 2, small map), and the local climatologic conditions (e.g. dry inner alpine valleys) play a significant role for the high number of lightning-caused fires as compared to other parts of Europe.
Fig. 5 Daily distribution per hour (UTC) of human-caused and lightning-caused fires $(n=1283)$

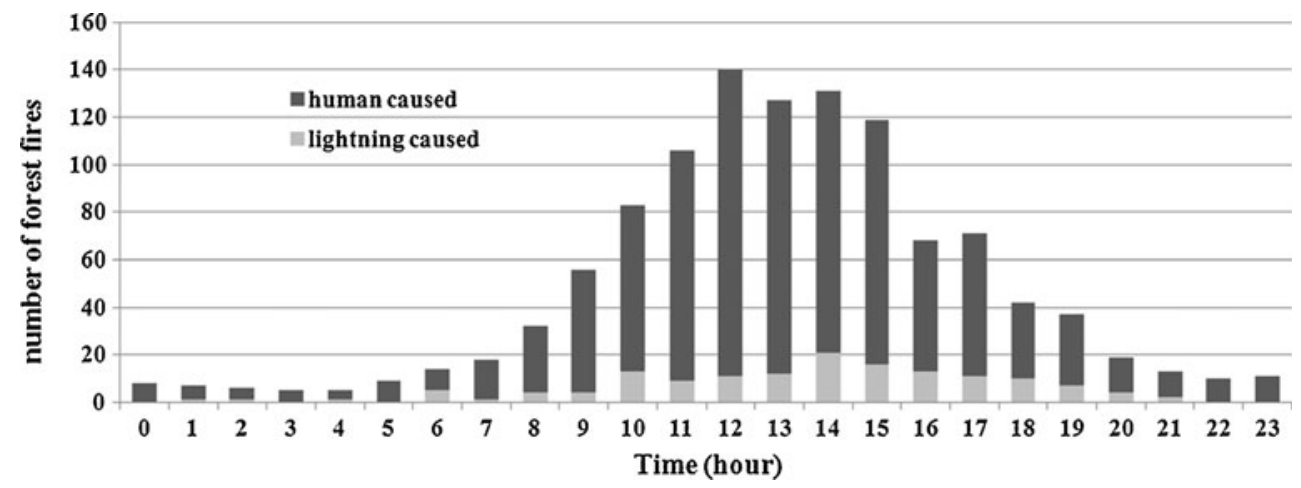


Fig. 6 Frequency of humancaused and lightning-caused fires according to altitudinal zones and forest area $(n=1591)$

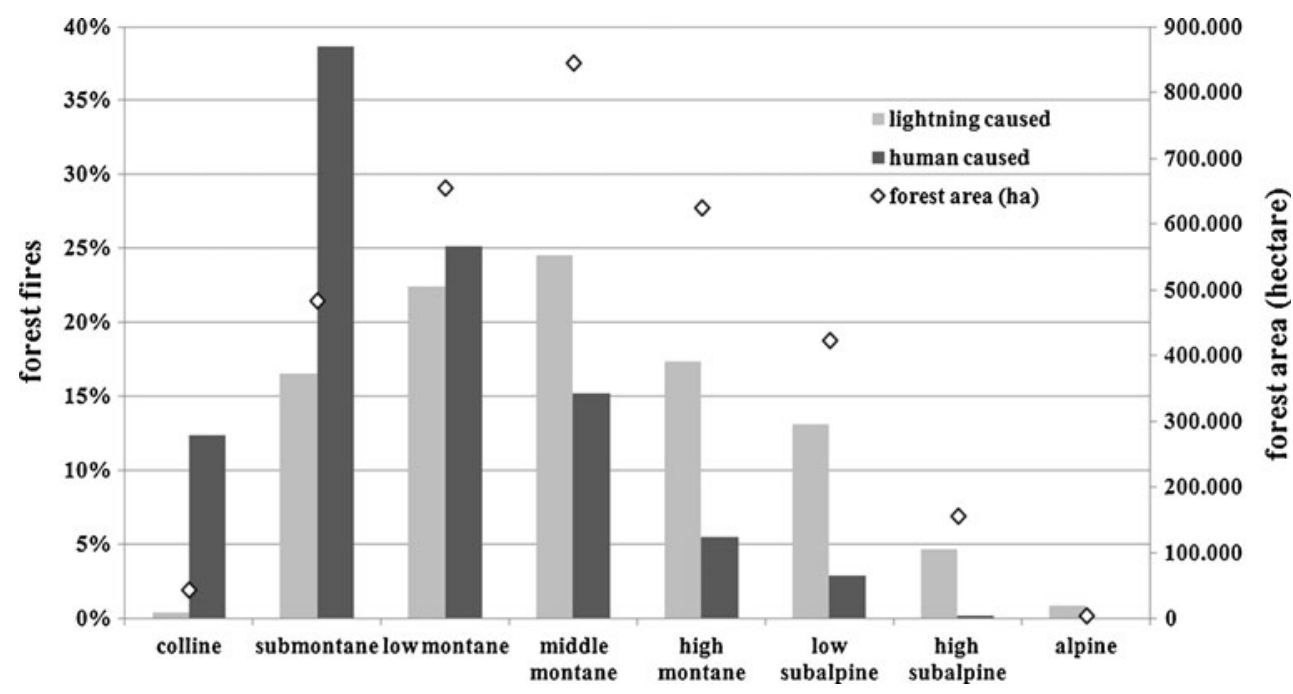

The spatial distribution of lightning fires is not uniform all over Austria. Obviously, lightning fires are more likely in the borderline of regions with higher and lower lightning density, especially in the southern parts of Lower Austria and Carinthia (cf. Fig. 2). This might be linked to the thunderstorm activity in general. While in areas with high lightning densities, high accumulations of precipitation can also be found (which prohibit lightning fires), in the drier edge regions, the possibility for lightning ignition increases. This supports the hypothesis that fuel moisture and drought are more important for ignition through lightning than the total number of lightning flashes (Larjavaara et al. 2005; Rorig and Ferguson 1999). A comparison between weather radar data and lightning location data could help on understanding the relationship between the amount of precipitation and the distribution of flashes in the future.

A reason for the temporal differences between reported lightning fires and human-caused fires during the day (cf. Fig. 5) may be found in the dynamics of thunderstorms. Forest fires ignited by humans are driven by the sun (temporal "hot spot" around 2 or $3 \mathrm{~h}$ after noon, naturally the time with highest ground temperatures and lowest humidity in the summer months). Thunderstorm activity normally starts early in the afternoon and reaches its peak around 1500 hours UTC (Schulz et al. 2005). This corresponds well with the most frequent time of reported lightning fires.

Yearly statistics (Fig. 4) show that drought in the summer seems to play a significant role concerning the number of lightning fires. This is consistent with many other studies (e.g. Conedera et al. 2006; Duncan et al. 2010; Le Page et al. 2008; Reinhard et al. 2005; Wendler et al. 2010). Climate scenarios for the future for the alpine region forecast both higher temperatures and, at least in some regions, an increase in number and severity of heat waves (Dankers and Hiederer 2008; Fischer and Schär 2010; Matulla et al. 2004; Wohlgemuth et al. 2008). Carinthia, and in the last years also southern parts of Styria, seem to get more affected by summer drought (Lautenschlager et al. 2005; Lautenschlager et al. 2009; ZAMG 2011). This corresponds to the general high number of forest fires in Carinthia. Keeping all this in mind, the role of lightninginduced forest fires in Austria, and generally in the alpine region, might get more important (Badeck et al. 2003; Conedera et al. 2006; Gossow and Frank 2003; Gossow et al. 2008).

The smaller median size of burned forest area through lightning fires compared to human-caused fires might be the result of both early detection and quick attacking by fire brigades, even in remote areas. During thunderstorm activity, local people seem to have a higher sensibility for natural disturbances, whereas lighting fires are discovered more rapidly. Direct manmade fires might be extinguished by the perpetrator before reported to the fire brigades. However, the Austrian fire brigade network is dense, as is the population in general. Even very small pasture fires are observed early by local people and reported to the authorities. Other explanations are related to the observation that human-caused fires often appear during peaks of heat waves, also in the presence of strong foehn winds, and thunderstorm activity is followed by rain and sometimes coupled with cold fronts that instigate a colder and moister weather period - reasons that may prohibit a larger spread of forest fires. Moreover, lightning fires are more prone to start as underground and/or smouldering fires (Wotton and Martell 2005). A longer smouldering period increases the probability of detection, while coincidently, the burning area stays small. Studies showed that lightning fires may burn larger areas than human-caused fires (Castedo-Dorado et al. 2011; Podur et al. 2003). Indeed, these analyses that are originated in Canada and Southern Europe, regions which comprise larger or horizontally more extended forest areas, provide fewer infrastructures through forest roads and have a lower density of fire brigades compared to Austria. However, the danger of larger burned forest area through lightning fires in Austria may increase in the future if the upward trend in 
temperature and maybe also the accumulation of heat waves in the alpine region continues (Dankers and Hiederer 2008; Fischer and Schär 2010; Lautenschlager et al. 2005; Lautenschlager et al. 2009; Matulla et al. 2004; Wohlgemuth et al. 2008).

A reason that lightning fires are more common in coniferous stands than human-caused fires might be that fires in broadleaf forests are often anthropogenic and originate from hot ashes, a pyre or green waste fire that got out of control. It is interesting to note that $18 \%$ of all human-caused fires occurred in broadleaf forests, while there are only $12 \%$ broadleaf forests in Austria (Austrian Forest Inventory (ÖWI) 2000/2002). A previous study from Switzerland found out that lightning fires were more likely to occur in coniferous and mixed coniferous forests, and humaninduced forest fires concentrated on deciduous-dominated stands (Reineking et al. 2010). Mixed forests (conifer-dominated forests with broadleaf make up $15 \%$ of the Austrian forests, while broadleaf-dominated forests with conifers are $11 \%)$ were less affected by both lightning and humancaused fires, which might be a tribute to a higher resistance against fire ignition in these forest communities. Pure conifer stands account for $62 \%$ of forested area in Austria. However, $82 \%$ of lightning fires were found in coniferous forests. This emphasises the importance of lightning fires in conifer stands. Also, pure conifer stands are more frequently present in higher altitudes due to their natural range; as lightning-caused forest fires occur at higher levels more often, the relation between coniferous forests and lightning is reasonable.

Comparing the number of lightning-caused fires per altitudinal zone, it becomes evident that the distribution follows the relative share of forested areas within the altitudinal zones. However, at higher altitudes, the relative number of lightning-caused fires is increasing, which underlines the role of the inducing topographic and climatic factors. Human-caused fires show another distribution as they are most frequent at lower altitudes with less forest area. This indicates the importance of anthropogenic influence (cf. Fig. 6). The higher number of lightning fires in mountainous regions might also be a result of more thunderstorm days and increased lightning density (Schulz et al. 2005). Additionally, the human influence, and therefore the anthropogenic ignition probability, at higher altitudes is lower than in the more densely populated valleys, basins and lowlands. The clear tendency towards higher altitudes of lightninginduced forest fires compared to anthropogenic fires is also in line with findings from other studies (Conedera et al. 2006; Keeley 1982).

Acknowledgments This research has been conducted partly within the frame of the AFFRI, which is funded by the Austrian Science Funds within the Translational Research Program with reference number L539N14, and by the European Project Alpine Forest Fire Warning System, which is funded by the European Regional Development Fund of the Alpine Space Program with the reference number 15-2-3-IT.
Open Access This article is distributed under the terms of the Creative Commons Attribution License which permits any use, distribution, and reproduction in any medium, provided the original author(s) and the source are credited.

\section{References}

Anderson K (2002) A model to predict lightning-caused fire occurrences. Int J Wildland Fire 11:163-172

Auer I, Böhm R, Jurkovic A, Lipa W, Orlik A, Potzmann R, Schöner W, Ungersböck M, Matulla C, Briffa K, Jones P, Efthymiadis D, Brunetti M, Nanni T, Maugeri M, Mercalli L, Mestre O, Moisselin J-M, Begert M, Müller-Westermeier G, Kveton V, Bochnicek O, Stastny P, Lapin M, Szalai S, Szentimrey T, Cegnar T, Dolinar M, Gajic-Capka M, Zaninovic K, Majstorovic Z, Nieplova E (2007) HISTALP — historical instrumental climatologically surface time series of the Greater Alpine Region. Int J Climatol 27:17-46

Austrian Lightning Detection and Information System (ALDIS) (2009) Lightning statistics Austria. http://www.aldis.at. Accessed 12 November 2009

Badeck FW, Lasch P, Hauf Y, Rock J, Suckow F, Thonicke K (2003) Steigendes klimatisches Waldbrandrisiko. Allgemeine Forstzeitschrift für Wald- und Forstwirtschaft (AFZ - DerWald), Deutscher Landwirtschaftsverlag $\mathrm{GmbH}$, Hannover

Badia A, Sauri D, Cerdan R, Llurdés JC (2002) Causality and management of forest fires in Mediterranean Environments: an example from Catalonia. Environ Hazards 4:23-32

Barriopedro D, Fischer EM, Luterbacher J, Trigo RM, García-Herrera R (2011) The hot summer of 2010: redrawing the temperature record map of Europe. Scienceexpress. doi:10.1126/science.1201224

Biagi CJ, Cummins KL, Kehoe KE, Krider PE (2007) National Lightning Detection Network (NLDN) performance in southern Arizona, Texas and Oklahoma in 2003-2004. J Geophys Res 112: D05208

Castedo-Dorado F, Rodriguez-Perez JR, Marcos-Menendez JL, Alvarez-Taboada MF (2011) Modelling the probability of lightning-induced forest fire occurrence in the province of León (NW Spain). For Syst 20(1):95-107

Conedera M, Cesti G, Pezzatti GB, Zumbrunnen T, Spinedi F (2006) Lightning induced fires in the Alpine Region: an increasing problem. V International Conference on Forest Fire Research, Coimbra, Portugal

Dankers R, Hiederer R (2008) Extreme temperature and precipitation in Europe: analysis of a high-resolution climate change scenario. Office for Official Publications of the European Communities Luxembourg, EUR 23291 EN

Diendorfer G (2007) Lightning location systems (LLS). In: IX International symposium on lightning protection. Foz do Iguaçu, Brazil, 26-30 November 2007

Duncan BW, Adrian FW, Stolen ED (2010) Isolating the lightning ignition regime from a contemporary background fire regime in east-central Florida, USA. Can J For Res 40:286-297

FG (2007). Forstgesetz 1975, Bundesgesetz vom 3. Juli 1975, mit dem das Forstwesen geregelt wird, StF: BGBl. Nr. 440/1975 last change BGBl. I Nr. 55/2007.

Fischer EM, Schär C (2010) Consistent geographical patterns of changes in high-impact European heatwaves. Nat Geosci 3. doi:10.1038/NGE0866

Flannigan MD, Stocks BJ, Wotton BM (2000) Climate change and forest fires. Sci Total Environ 262(3):221-229

Gimmi U, Bürgi M, Wohlgemuth T (2004) Wie oft brannte der Walliser Wald im 20. Jahrhundert? Schweiz Z Forstwes (SZF) 10:437-440 
Goldammer JG (2002) Towards international cooperation in managing forest fire disasters in the Mediterranean Region. Int For Fire News IFFN 27:81-89

Gossow H, Frank G (2003) Waldbrand auf Windwurf - eine unheilige Allianz? Oesterreichische Forstztg 114(9):8-9

Gossow H, Hafellner R, Arndt N (2008) More forest fires in the Austrian Alps - a real coming danger? Borsdorf et al. (ed) Managing Alpine future, proceedings innsbruck conference 2007, IGF Forschungsberichte 2:356-362

Gossow H, Hafellner R, Vacik H, Huber T (2009) Major fire issues in the Euro-Alpine Region - the Austrian Alps. Int For Fire News IFFN 38:1-10

Hall BL, Brown TJ (2006) Climatology of positive polarity flashes and multiplicity and their relation to natural wildfire ignitions. In: 19th International lightning detection conference, Tucson, Arizona, USA

Keeley JE (1982) Distribution of lightning- and man-caused wildfires in california. In: Symposium on Dynamics and management of Mediterranean type ecosystems, Pacific southwest forest and range experiment station, forest service, U.S. Department of Agriculture, Berkeley, California

Larjavaara M, Pennanen J, Tuomi TJ (2005) Lightning that ignites forest fires in Finland. Agric For Meteorol. doi:10.1016/ j.agrformet.2005.07.005

Lautenschlager M, Keuler K, Wunram C, Keup-Thiel E, Schubert M, Will A, Rockel B, Boehm U (2005) Climate simulation with CLM, climate of the 20th century run no.3, data stream 3: European region MPI-M/MaD. World Data Center for Climate

Lautenschlager M, Keuler K, Wunram C, Keup-Thiel E, Schubert M, Will A, Rockel B, Boehm U (2009) Climate simulation with CLM, scenario alb run no.2, data stream 3: European region MPI-M/MaD. World Data Center for Climate

Le Page Y, Pereira JMC, Trigo R, Da Camara C, Oom D, Mota B (2008) Global fire activity patterns (1996-2006) and climatic influence: an analysis using the world fire atlas. Atmos Chem Phys 8:1911-1924

Matulla C, Formayer H, Haas P, Kromb-Kolb H (2004) Mögliche Klimatrends in Österreich in der ersten Hälfte des 21. Jahrhunderts. Österreichische Wasser- und Abfallwirtschaft (ÖWAW) 56:1-2

Müller MM (2010) Analyse der durch Blitzschlag ausgelösten Waldbrände in Österreich. Master thesis, University of Natural Resources and Life Sciences (BOKU), Vienna
Outcalt KW (2008) Lightning, fire and longleaf pine: using natural disturbance to guide management. For Ecol Manag 255:3351-3359

Podur J, Martell DL, Csillag F (2003) Spatial patterns of lightning caused forest fires in Ontario, 1976-1998. Ecol Model 164:1-20

Reineking B, Weibel P, Conedera M, Bugmann H (2010) Environmental determinants of lightning- v. human-induced forest fire ignitions differ in a temperate mountain region of Switzerland. Int $\mathbf{J}$ Wildland Fire 19:541-557

Reinhard M, Rebetez M, Schlaepfer R (2005) Recent climate change. Rethinking drought in the context of Forest Fire Research in Ticino, South of Switzerland. Theor Appl Climatol 82(1-2):1725

Rorig ML, Ferguson SA (1999) Characteristics of lightning and wildland fire ignition in the Pacific Northwest. J Appl Meteorol 38:1565-1575

Schulz W, Cummins KL, Diendorfer G, Dorninger M (2005) Cloud-toground lightning in Austria: a 10-year study using data from a lightning location system. J Geophys Res 110

Vacik H, Arndt N, Arpaci A, Koch V, Müller M, Gossow H (2011) Characterisation of forest fires in Austria. Austrian J For Sci 128 (1): $1-32$

Valese E (2007) Wildland fires in the Alpine region of Italy: what's old, what's new. What's next? Int For Fire News IFFN 38

Vega-Garcia C, Woodard PM, Titus SJ, Adamowicz WL, Let BJ (1995) A logit model for predicting the daily occurrence of human caused forest fires. Int J Wildland Fire 52:101-111

Wendler G, Conner J, Moore B, Shulski M, Stuefer M (2010) Climatology of Alaskan wildfires with special emphasis on the extreme year of 2004. Theor Appl Climatol 104:459-472

Wohlgemuth T, Brang P, Conedera M, Dobbertin M, KupferschmidAlbisetti A, Moser B (2008) Effekte des Klimawandels auf Windwurf, Waldbrand und Walddynamik im Schweizer Wald. Schweiz Z Forstwes (SZF) 159(10):336-343

Wotton BM, Martell DL (2005) A lightning fire occurrence model for Ontario. Can J For Res 35:1389-1401

Zentralanstalt für Meteorologie und Geodynamik (ZAMG) (2011) HISTALP Langzeitklimareihen - Oesterreich, Sommerbericht 2011. Historical instrumental climatological surface time series of the greater alpine region (HISTALP), Central Institute for Meteorology and Geodynamics, Department of Climate Research, Vienna 